\title{
The Effect of Cultural and Working Discipline on Performance of Civil Apparatus
}

\author{
Ismet Sulila ${ }^{1} \quad$ Rudi Naue ${ }^{2}$ \\ 1.Study Program of Public Administration, Faculty of Economics, Gorontalo State University, Indonesia \\ 2.Study Program of Public Administration Science, Postgraduate Program of Gorontalo State University, \\ Indonesia
}

\begin{abstract}
This research aims to examine the effect of work culture and work discipline on performance of State Civil Apparatus of Financial Board in Gorontalo City, both partially and simultaneously. This research uses quantitative approach. The research method is ex post facto. The research design is causality. The data analysis technique is multiple regressions. The research results showed that (1) Work culture has a positive and significant effect on performance of State Civil Apparatus of Financial Board in Gorontalo City, (2) Work discipline has positive and significant effect on performance of State Civil Apparatus of Financial Board in Gorontalo City, and (3) Work culture and Work discipline Culture simultaneously have positive and significant effect on performance of State Civil Apparatus of Financial Board in Gorontalo City. Based on these results, the recommendation can be stated as follow. First, Local Apparatus Work Unit leaders and regional leaders should make a regulation that provides conducive environment to work culture. Second, the leadership must approve rewards and penalties for employees. Third, cooperation must be supported by all elements in a government or an area of government.
\end{abstract}

Keywords: Civil Apparatus Performance, Work Culture, Work Discipline

DOI: $10.7176 /$ PPAR/10-1-03

Publication date: January $31^{\text {st }} 2020$

\section{INTRODUCTION}

The enactment of Law Number 9 Year 2015 as Amendment to Law Number 23 Year 2014 on Regional Government in lieu of Law Number 32 Year 2004 and Law Number 2 Year 1999 provide regions more freedom to serve and bring prosperity to community. This law makes the maximum utilization of government apparatus greatly affects the smooth running of government and development in era of regional autonomy. This success is very affected by performance of individual apparatus.

Sinambela et al (2012) suggest that employee performance is defined as an employee's ability to perform certain skills. Robbins (2006) determined employee performance as the result or achievement of work determined by organization. Good performance is optimal performance that consistent with organizational standards and supporting the achievement of organizational goals. The process to achieve employee work outcomes relates with work culture and work discipline in training environment. Work culture consists of several aspects related to employee work behavior oriented to service, integrity, commitment, and cooperation.

Organizational culture is one strategy to motivate employees to achieve maximum goals, and a good organizational culture will automatically provide assistance in accordance with employees needs work in accordance with employee culture that is very suitable and supports employees to develop welfare. In other words, organizational culture becomes an important factor to improve performance through work obtained by employees in company (Wahab, 2002: 10). In addition to culture, another important factor is employee work discipline.

Discipline is a management action to encourage organization members to meet various provisions. The discipline application is more demanded on individuals who are not aware to the applicable regulations in organization (Simmamora, 2003: 3). This is reinforced by statement of Raharjo (2012: 7) which shows the work coordination variable on employee performance variables. In this case, discipline is important for reason organizations will be obeyed by most employees and it is expected that work will be carried out effectively and to improve employee performance.

Performance can be increased through a work culture and work discipline that well implemented in government administration environment. Robbins (2006: 292) stated about the strong work culture will be seen from how employees perceive work culture will improve employee work which can be seen from employee attitudes, high commitment, and employee creativity itself. The employee work discipline consists of work coordination and obeying applicable rules and regulations, meetings and coordination of working hours, use and maintenance of equipment that can be used to support office activities to run smoothly.

Discipline issues, especially the discipline of State Civil Apparatus, still receive a sharp focus from public to day. Apparatus caught in disciplinary raids have been subject to disciplinary sanctions. Violations and disciplinary problems have hampered the function of government services due to existence of State Civil 
Apparatus who did not do their duties optimally. Civil Servants Discipline Regulations are regulated in Government Regulation Number 30 of 1980 on Civil Servants Discipline Regulations that are updated with Government Regulation Number 53 year 2010. Regulation of State Civil Apparatus Discipline Regulations manage the obligations, prohibitions, disciplinary punishments, authorized officials convict, disciplinary punishment, objection of disciplinary punishment, applicability of disciplinary judgment.

The performance of authorities has always been an issue that often discussed in various Government agencies in Gorontalo City, as the case of Gorontalo City Financial Board, as an agency engaged in management and formulation of Regional Budget. However, the reality the performance is not consistent with expectation; this can be seen from data of Financial Board regarding the results of last two years State Civil Apparatus assessment, as shown in table 1.

Table 1. Civil Apparatus Performance of Regional Finance at Gorontalo City

\begin{tabular}{|l|l|c|c|c|c|}
\hline No & Elements & \multicolumn{2}{|c|}{ Year 2018 } & \multicolumn{2}{c|}{ Year 2019 } \\
\hline & & Score & Description & Score & Description \\
\hline 1 & Loyalty & 85 & Good & 78 & Inadequate \\
\hline 2 & Responsibility & 82 & Good & 78 & Inadequate \\
\hline 3 & Cooperation & 82 & Good & 76 & Inadequate \\
\hline 4 & Work quality & 80 & Good & 72 & Inadequate \\
\hline 5 & Work quantity & 80 & Good & 70 & Inadequate \\
\hline 6 & Skill & 80 & Good & 72 & Inadequate \\
\hline & Total & 489 & & 446 & Inadequate \\
\hline
\end{tabular}

Source: Local Financial Board of Gorontalo City, 2019

Table 1 show that average performance of State Civil Apparatus of Financial Board in Gorontalo City has been good in 2018, but in 2019 State Civil Apparatus performance has decreased to become $74.30 \%$. The decrease was seen in indicators of loyalty, responsibility, cooperation, work quantity, work quality, and work skills are quite significant, so it is indicated that in 2019 there will be problems with State Civil Apparatus performance.

Low performance was occurred because the work culture and work discipline still low. This can be seen from the absence of a strong and positive organizational culture to improve the behavior and attitudes of apparatus. There are still officers who often delay work and do not use the free time properly in carrying out their duties. There are still officials who do not have high commitment who apathetic towards the regulations / rules set, there are still officers who are not disciplined in work, this can be seen from employees who are unable to complete the tasks given by superiors in accordance with a predetermined time, lack of discipline or breaking the rules, leaving work without permission, lack of employee attendance on time and behavior that shows low morale. The employees do their duties according to rules and guidelines set by organization. In order to achieve the expected employee performance, several influential factors are organizational culture and work discipline, so that if this is allowed to continue, Gorontalo City Financial Board will not produce qualified officers because they cannot do their duties properly.

Above phenomenon motivates researchers to conduct research with following problem formulation:

1. Does work culture affect the performance of State Civil Apparatus of Financial Board in Gorontalo City?

2. Does work discipline affect the performance of State Civil Apparatus of Financial Board in Gorontalo City?

3. Does work culture and work discipline simultaneously affect the performance of State Civil Apparatus of Financial Board in Gorontalo City?

\section{RESEARCH METHODS}

This research was conducted at Regional Financial Board of Gorontalo City. The time for conducting the research is 5 months, from September 2019 to January 2020. The definition of operational variables is shown in table 2 . 
Table 2. Conceptual Definitions and Operational Definitions

\begin{tabular}{|l|l|l|}
\hline Variables & Conceptual Definition & Operational Definition/Indicator \\
\hline Work Culture & $\begin{array}{l}\text { A work situation that allows all } \\
\text { employees to do all work in best way } \\
\text { that can be done. }\end{array}$ & $\begin{array}{l}\text { 1) Innovation, 2) Attention to details, 3) } \\
\text { Results orientation, 4) Team Orientation, 5) } \\
\text { Aggressiveness, 6) Stability (Robbins, 2006: } \\
\text { 143) }\end{array}$ \\
\hline Discipline Work & $\begin{array}{l}\text { Every individual and group ensures to } \\
\text { compliance with orders and takes the } \\
\text { initiative to take an action needed if there } \\
\text { are no orders. }\end{array}$ & $\begin{array}{l}\text { 1) Understanding the rules, 2) Sanctions, 3) } \\
\text { Obedience, 4) Awareness, 5) Timely } \\
\text { (Pasolong, 2002: 145) }\end{array}$ \\
\hline $\begin{array}{l}\text { State } \\
\text { Apparatus }\end{array}$ & $\begin{array}{l}\text { Performance is the ability to realize the } \\
\text { work ability of employees in accordance } \\
\text { with duties and responsibilities of work } \\
\text { they done. }\end{array}$ & $\begin{array}{l}\text { 1) Work Quality, 2) Work Quantity, 3) } \\
\text { Timeliness (Bastian, 2007: 155) }\end{array}$ \\
\hline
\end{tabular}

The population of this research were all 123 employees of Financial Board at Gorontalo City. Total 81 respondents were selected by purposive sampling. The data analysis used is multiple regressions as follows (Arikunto, 2006; Ghozali, 2005) :

Where:

$$
\mathbf{Y}=\mathbf{a}+\mathbf{b}_{1} \mathbf{X}_{1}+\mathbf{b}_{2} \mathbf{X}_{2}+\mathbf{e}
$$

$\mathrm{Y}=$ Employee Performance

a $=$ Constant

$\mathrm{b}=$ direction of regression coefficient.

$\mathrm{X} 1=$ Work Culture

$\mathrm{X} 2=$ Work Discipline

\section{RESEARCH RESULT}

A. Estimation of Multiple Regression Model

The results of multiple regression analysis are shown in table 3.

Table 3. Regression Analysis Results

\begin{tabular}{|c|c|c|c|c|c|c|}
\hline & \multirow{2}{*}{ Model } & \multicolumn{2}{|c|}{ Unstandardized Coefficients } & \multirow{2}{*}{$\begin{array}{c}\text { Standardized Coefficients } \\
\text { Beta }\end{array}$} & \multirow{2}{*}{$\mathbf{t}$} & \multirow{2}{*}{ Sig. } \\
\hline & & B & Std. Error & & & \\
\hline \multirow{3}{*}{1} & (Constant) & 11.907 & 3.755 & & 3.171 & .002 \\
\hline & Work Culture & 0.408 & .082 & .458 & 4.958 & .000 \\
\hline & Work Discipline & 0.309 & .092 & .309 & 3.345 & .001 \\
\hline
\end{tabular}

Source: Data processed by SPSS 21, 2019.

Based on results above, the multiple regression model is developed below.

B. Hypothesis Testing

$$
\hat{\mathbf{Y}}=11,907+0,408 X_{1}+0,309 X_{2}+e
$$

\section{Partial Hypothesis Testing}

The results of hypotheses testing are seen in table 4 .

Table 4. Partial Test Results

\begin{tabular}{ccccc}
\hline No & Variables & $\boldsymbol{\beta}$ & $\mathbf{T}_{\text {count }}$ & P-Value \\
\hline 0 & Constant & & 3.171 & 0.002 \\
1 & Work Culture & .458 & 4.958 & 0.000 \\
2 & Work Discipline & .309 & 3.345 & 0.001 \\
\hline
\end{tabular}

Source: Data processed by SPSS 21, 2019

Testing the effect of each independent variable (work culture and work discipline) on performance of State Civil Apparatus of Financial Board in Gorontalo City can be explained below.

a) The Effect of Work Culture on Performance of State Civil Apparatus

Table 4 show that value of $t$-count is still greater than the table-figures $(4,958>1,991)$. Therefore it is concluded that work culture has a positive and significant effect on performance of State Civil Apparatus of Financial Board in Gorontalo City.

\section{b) The Effect of Work Discipline on Performance of State Civil Apparatus}

Table 4 show that $\mathrm{t}$-count value is greater than the t-table value $(3.345>1.991)$. Therefore it is concluded that work discipline has a positive and significant effect on performance of State Civil Apparatus of Financial Board in Gorontalo City. 


\section{Simultaneous Hypothesis Testing}

The results of simultaneous hypothesis testing can be seen in table 5 .

Table 5. Simultaneous Testing Results

\begin{tabular}{|c|c|c|c|c|c|c|}
\hline \multicolumn{2}{|c|}{ Model } & Sum of Squares & df & Mean Square & F & Sig. \\
\hline \multirow{2}{*}{1} & Regression & 779.863 & 2 & 389.932 & 23.088 & $.000^{\mathrm{b}}$ \\
& Residual & 1317.335 & 78 & 16.889 & & \\
& Total & 2097.199 & 80 & & & \\
\hline
\end{tabular}

Source: Data processed by SPSS 21, 2019

Table 5 shows the F-value is 23.008 with a significance of $0.000<0.05$. This means that work culture and work discipline simultaneously have a positive and significant effect on performance of State Civil Apparatus of Financial Board in Gorontalo City.

3. Determination Coefficient

The magnitude of coefficient of determination $\left(\mathrm{R}^{2}\right)$ in this research can be seen in following table 6 .

Table 6. Coefficient of Determination

\begin{tabular}{|c|c|c|c|c|}
\hline Model & R & R Square & Adjusted R Square & Std. Error of the Estimate \\
\hline 1 & $.610^{\mathrm{a}}$ & .372 & .356 & 4.10961 \\
\hline
\end{tabular}

Source: Data processed by SPSS 21, 2019

Table 6 shows the adjusted value of $\mathrm{R}^{2}$ or adjusted coefficient of determination of 0.356 which shows that $35.60 \%$ performance variability of performance of State Civil Apparatus of Financial Board in Gorontalo City. It can be explained by work culture and work discipline, while the remaining $64.40 \%$ can be explained by other variables not examined in this research such as communication, leadership style, employee competency, employee work commitment, information technology support, understanding of regional financial accounting system, and cooperation between employees.

The effect for each variable of results is presented in table 7.

Table 7. Partial Determination Coefficient

\begin{tabular}{|c|c|c|c|c|}
\hline \multirow{2}{*}{ Model } & \multirow{2}{*}{ Standardized Coefficients } & \multirow{2}{*}{ Correlation } & \multicolumn{2}{|c|}{ Determination } \\
\cline { 3 - 5 } & & & Value & \% \\
\hline Work Culture & 0.458 & 0.531 & 0.243 & $24.30 \%$ \\
\hline Work Discipline & 0.309 & 0.417 & 0.129 & $12.90 \%$ \\
\hline \multicolumn{2}{|c|}{ Simultaneous determination coefficient } & 0.372 & $37.20 \%$ \\
\hline
\end{tabular}

Source: Data processed by SPSS 21, 2019

Table 7 shows the partial determination analysis for the effect of work culture on performance of State Civil Apparatus of Financial Board in Gorontalo City is $24.30 \%$ with highest element is the culture to do work on time. The effect of work discipline on performance of State Civil Apparatus of Financial Board in Gorontalo City is $12.90 \%$ with highest element is discipline to maintain good performance at work.

\section{DISCUSSION}

\section{A. The Effect of Work Culture on Performance of State Civil Apparatus}

Regression test results showed that t-test value was still greater than the t-table value (4.958> 1.991). Therefore it is concluded that work culture has a positive and significant effect on performance of State Civil Apparatus of Financial Board in Gorontalo City. The positive coefficient means that if Financial Board employees at Gorontalo City can create a conducive work culture then it will have a good impact to improve the performance of State Civil Apparatus to manage regional finances.

One important role of work culture values on employee performance is to increase the motivation. The maximum relationship between performance and work culture through motivation is clearly felt by an organization that has a philosophy / essence of strong values both in terms of internal environment and external environment of organization. Sadu (2000) stated that work culture helps performance because it creates an extraordinary level of motivation for employees.

Descriptive test results indicate that work culture variable lies in good criteria with a score of $84.94 \%$. This shows that Financial Institution in Gorontalo City has a work culture to make a job easy for employees and is an important factor to increase the intensity of coordination and communication to strengthen the work of employees. A good work culture will certainly encourage to improve employee performance.

This result is consistent with opinion of Putranto (2012: 11) that all organizations have a culture that depends on their strengths. Culture can have a significant effect on attitudes and behavior of organization members. Abdussamad (2014: 2) revealed that acceleration of environment changes can changes the work culture. The research results found a significant effect of work culture on performance quality of State Civil Apparatus, it is consistent with research conducted by Serdamayanti (2009) that leaders must strive to create 
conducive work culture conditions and can support the creation of good performance. In addition, the importance of work culture still needs to be socialized.

Overall, it can be conveyed the synthesis of first hypothesis testing that work culture has a positive and significant effect on performance of State Civil Apparatus of Financial Board in Gorontalo City. The work culture of an organization is believed to be a major determining factor for the success of an organization's performance.

\section{B. The Effect of Work Discipline on Performance of State Civil Apparatus}

Regression test results found that $t$-value is greater than the t-table value $(3.345>1.991)$. Therefore, it is concluded that work discipline has a positive and significant effect on performance of State Civil Apparatus of Financial Board in Gorontalo City. The positive coefficient shows that better work discipline will improve the performance of State Civil Apparatus of Financial Board in Gorontalo City to achieve Good Governance. These results indicate that leaders should implement reward and punishment for employees or State Civil Apparatus of Financial Board in Gorontalo City where there must be a praise for disciplined employees and there must strict sanctions to employees who often violate and not disciplined, especially in terms of time discipline.

The results of this research are consistent with Dapu (2015) that Discipline and Leadership have positive and significant effect on Employee Performance. Setiawan (2013) also said that work discipline of an apparatus is not only seen from absenteeism, but can also be judged by attitude of employee to do job. High discipline apparatus does not delay work and always try to finish on time even though there is no direct supervision from superiors. It can be said that work discipline will affect the performance of apparatus to complete their job.

Descriptive results indicate that work discipline variable is located in a fairly good criterion with a score of 77.30\%. This shows that State Civil Apparatus of Financial Board in Gorontalo City has compliance with applied rules to do the work well in accordance with specified targets. However, they need for time disciplinary improvement even though the discipline is good. The results of this research are consistent with Susiarto and Ahmadi (2006: 65) that apparatus work discipline is one determinants of employee performance. Prasetyo (1984: 72) stated that one determinants of performance was work discipline. The work discipline of an apparatus is not only seen from absenteeism, but can also be judged by their attitude to do job.

Overall, this research results can be synthesized, especially in testing the second hypothesis that Work Discipline has a positive and significant effect on performance of State Civil Apparatus in Gorontalo City Financial Board. Good discipline shown by employees will show that an organization can maintain loyalty and quality of its employees. In addition, by knowing the work discipline of apparatus, the work value of employees will also be known. Employee work discipline can affect the performance of apparatus because by having a high work discipline, an apparatus will do tasks and work effectively and efficiently so that performance of apparatus can further improve and will have an impact to achieve organizational goals.

\section{Simultaneous Effect of Work Culture and Work Discipline on Performance of State Civil Apparatus}

Adjusted $\mathrm{R}^{2}$ value is 0.356 . This shows that $35.60 \%$ variability of performance of State Civil Apparatus of Financial Board in Gorontalo City can be explained by work culture and work discipline, while the remaining $64.40 \%$ can be explained by other variables not examined in this research such as communication, leadership style, employee competence, employee work commitment, information technology support, understanding of regional financial accounting system, and cooperation between employees.

The regression test shows that work culture and work discipline simultaneously have a positive and significant effect on performance of State Civil Apparatus of Financial Board in Gorontalo City. It indicates strong and positive implications of these two factors as a catalyst to optimize the performance of State Civil Apparatus of Financial Board in Gorontalo City. This result is consistent with Siswanto (2009: 277) that workers discipline become an impulse that arises from themselves and runs in accordance with rhythm of program's rotation and workload. Setiawan (2013) said that performance was affected by work discipline. Discipline was a form of adherence to rules, both written and unwritten.

Hatalea et al. (2014) explained that strong work culture will be seen from how employees perceive work culture. It will affect the behavior described as high motivation, dedication, creativity, ability and commitment. Stronger work culture will increase the employees productivity and community satisfaction. Work culture can be realized after going through a long process. This is because the change of old values into new values will take time to become toxic and unceasingly continues to make improvements. The personality becomes an attitude, then becomes a behavior that contains an element of enthusiasm, discipline, diligent, honest, responsibility, saving, integrity; so that work will achieve high quality and satisfaction.

The potential of human resources has a very important role as actors involved in current industrial development process. The employee performance to produce products with good quality and quantity in accordance with standards will gain public trust. Employee performance is the result of quality and quantity of work achieved by an employee in carrying out their duties in accordance with responsibilities given to him. The 
existence of work discipline is needed in an organization because in an atmosphere of discipline the organization will be able to do its work programs to achieve the targets set (Mahmudi, 2007)

The analysis results for respondents' answers found that performance of State Civil Apparatus lies in good criteria with an achievement score of $83.80 \%$. This shows that State Civil Apparatus of Financial Board in Gorontalo City have optimal work results. They success to complete the job as evidenced by apparatus ability to contribute financial management, goods and services that reasonable in Gorontalo City. BPK assessment for financial performance and regional financial management in Gorontalo City for 5 consecutive years is a Fair Opinion without Exception.

It can be synthesized from results of third hypothesis testing that Work Culture and Work Discipline simultaneously together have a positive and significant effect on performance of State Civil Apparatus of Financial Board in Gorontalo City. Work culture is always expected to be good because the good work culture will relate to success or failure to achieve organizational goals. A good organizational culture will facilitate organization to overcome the problems faced and can achieve organizational goals by relying on strengths in organization. A good organizational culture usually affect the performance of its employees. It can be concluded, the better the culture of an organization can improve the performance of employees.

\section{CONCLUSION}

Based on results of research and above discussion, the conclusions can be summarized below.

1. Work culture has a positive and significant effect on performance of State Civil Apparatus of Financial Board in Gorontalo City. If State Civil Apparatus of Financial Board in Gorontalo City can create a conducive work culture, it will have a good impact to improve the performance quality of State Civil Service to manage regional finances.

2. Work discipline has a positive and significant effect on performance of State Civil Apparatus of Financial Board in Gorontalo City. The better work discipline within agency will improve the performance of State Civil Apparatus of Financial Board in Gorontalo City to achieve Good Governance.

3. Work culture and work discipline simultaneously have a positive and significant effect on performance of State Civil Apparatus of Financial Board in Gorontalo City.

\section{SUGGESTION}

Based above conclusions described above, the research recommendations are below.

1. Local Apparatus Work Unit leaders and regional leaders should strive to create rules and regulations that are able to have a conducive impact on work culture.

2. The leaders should apply the reward and punishment for State Civil Servants of Financial Board in Gorontalo City. There must be praise to disciplined apparatus and there must also be strict sanctions to apparatus that often violate and undisciplined, especially in terms of time discipline.

3. Cooperation between all elements in an agency must be improved. This cooperation will encourage higher communication and coordination so that all work can be completed properly in accordance with provisions of quality, quantity requirements and provisions of effective and efficient time.

\section{REFERENCES}

Abdussamad, Juriko. 2014. Analisis Budaya Organisasi Dalam Meningkatkan Kinerja Pada Dinas Pendidikan Pemuda Dan Olahraga Provinsi Gorontalo. Jurnal Administrasi Publik

Arikunto, Suharsimi. 2006. Prosedur Penelitian Suatu Pendekatan Praktik. Jakarta: Rineka Cipta.

Dapu, Valensia Angelina Wisti. 2015. The influence of work discipline, leadership, and motivation on Employee performance at PT. Trakindo utama manado. Journal EMBA Vol.3 No.3 Sept. 2015, Hal.352-361

Indra, Bastian. 2007. Sistem Akuntansi Sektor Publik. Jakarta. Salemba Empat.

Ghozali, Imam. 2005. Aplikasi Analisis Multivariate dengan SPSS. Semarang: Badan Penerbit UNDIP.

Hatalea, Amna; Sugeng Rusmiwari; dan Akhirul Aminulloh. 2014. Budaya Kerja Pegawai Negeri Sipil. JISIP: Jurnal Ilmu Sosial dan Ilmu Politik ISSN. 2442-6962 Vol. 3, No. 2 (2014)

Pasolong, Harbani. 2007. Teori Administrasi Publik. Bandung: Penerbit Alfabeta.

Suit, Jusuf dan Almasdi. 2012. Aspek Sikap Mental Dalam Manajemen Sumber Daya. Manusia, Jakarta: Syiar Media

Mahmudi, 2007, Manajemen Kinerja Sektor Publik. Yokyakarta: UPP STIM YKPN

Prasatyo, Adi Dipta dan Susilo Toto Raharjo. 2012. Pengaruh Disiplin Kerja Dan Budaya Organisasi Terhadap Kinerja Karyawan Pabrik Minyak Kayu Putih (PMKP) di Krai Purwodadi, Diponegoro Journal of Management,Vol.I, No. I, 2012

Putranto, Danang Indra, 2012, Pengaruh Komunikasi Internal, Kompensasi Kerjadan Lingkungan Kerja Terhadap Kepuasan Kerja Karyawan pada PT. KimiaFarma Plant Semarang, Diponegoro Journal of Social and Politic. 1-9 
Robbins, P. Stephen. 2006. Perilaku Organisasi. Edisi Sepuluh. Diterjemahkan oleh: Drs. Benyamin Molan. Erlangga, Jakarta.

Sedarmayanti, 2009, Good Government (Pemerintahan yang baik); Bandung: CV. Mandar Maju.

Setiawan, Agung. 2013. "Pengaruh Disiplin Kerja Dan Motivasi Terhadap Kinerja Karyawan Pada Rumah Sakit Umum Daerah Kanjuruan Malang”. Jurnal Ilmu Manajemen. Vol 1, No 4; Juli 2013.

Simamora, Henry, 2003, Manajemen Sumber Daya Manusia, Edisi Ketiga, CetakanPertama, Bagian Penerbitan STIE YKPN, Yogyakarta

Sinambela, Lijan., 2011, Reformasi Pelayanan Publik, Jakarta, Penerbit PT. Bumi Aksara.

Siswanto, H. B. 2009. Pengantar Manajemen, Bumi Aksara, Jakarta.

Susiarto dan ahmadi, Slamet. 2006, "Analisis Pengaruh Pelatihan dan Kedisiplinan Terhadap Kinerja Pegawai Operator di SPBU Jakarta Selatan," Jurnal manajemen dan Kewirausahaan 4 (1): 34-41.

Wahab, Solichin. 2002. Analisis Kebijaksanaan, Dari Formulasi Ke. Implementasi Kebijaksanaan Negara. Jakarta: Bumi Aksara

Sadu, Wasistiono, 2000, Kapita Selekta Penyelenggaraan Pemerintah Daerah. Jakarta: Ghalia Utama. 